\title{
Selected problems and challenges of ophthalmic care system in Poland
}

\section{Maciej 0sęka', Agnieszka Jamrozy-Witkowska², Małgorzata Mulak}

${ }^{1}$ Foundation of the Prevention of Eye Diseases and Oftalabs Sp. z 0.0.

Chair: Maciej Osęka, MD, PhD

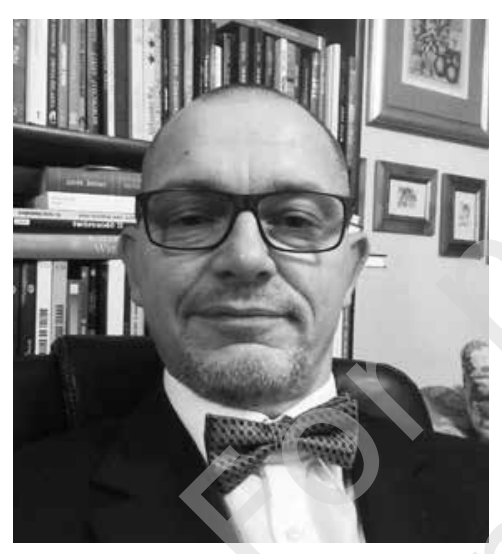

${ }^{2}$ Optegra Eye Hospital in Warsaw

Medical Director: Jolanta Oficjalska, MD, PhD

${ }^{3}$ Department of Ophthalmology, Wroclaw Medical University Head: Prof. Marta Misiuk-Hojto, MD, PhD

\section{H I G HLIGHTS}

The increase in the occurrence of refractive errors and eye diseases, and the shortage of ophthalmologists and support staff are the main problems of the ophthalmic care system in Poland. 


\section{INTRODUCTION}

Demographic changes and the increase in the incidence of selected eye diseases create a challenge for the ophthalmic care system worldwide. The purpose of this article is to identify the main problems that are or will be encountered in the near future in ophthalmic care in Poland.

\section{AGING OF THE POPULATION}

Data from the Polish Central Statistical Office (GUS, Główny Urząd Statystyczny) from year 2018 show that $38.4 \mathrm{mln}$ people currently live in Poland. The most numerous age groups are people aged 25-29 to 65-69 (fig. 1). Age groups of children and adolescents in the age range from
$0-4$ to $20-24$ years are the least numerous. According to the data published in year 2016 by GUS and covering the expected demographic changes in Poland until year 2050, the group of people aged 60 years and above will gradually increase. Currently, according to data for year 2018, this is $24 \%$ of Polish population. According to the GUS forecast, in year 2030 this percentage will be nearly $30 \%$, and in year 2050 it will exceed $40 \%$ (fig. 2). This will be accompanied by an increase in the length of life. For people born in year 2050, the length of life will increase by 9 and 6.4 years for women and men, respectively (the current length of life is 87.5 years for women and 81.1 years for men) [1,2]. Along with the increase in life expectancy the occurrence of age-related diseases, also eye diseases will increase.

\section{FIGURE 1}
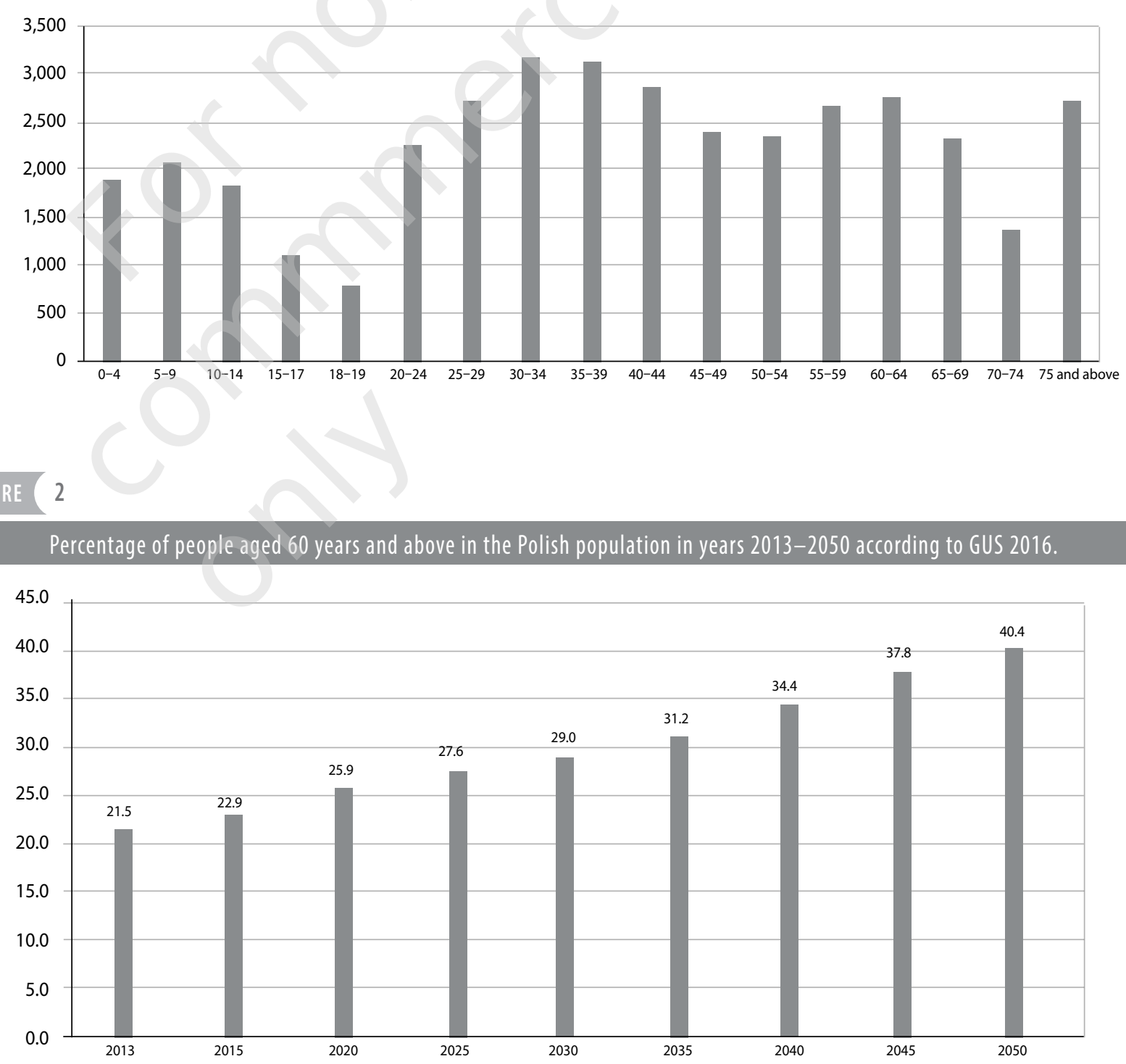


\section{INCREASED OCCURRENCE OF REFRACTIVE ERRORS AND CHRONIC EYE DISEASES}

In Poland, according to the GUS report Health condition of the Polish population in 2014, there are currently about $4.7 \mathrm{mln}$ disabled people aged 15 and above. Over $35 \%$ of them have eye damage or diseases. About $50 \%$ of the adult population in Poland use glasses, and refractive disorders are the most common eye disease in children aged up to 15 years and people aged 60 years and above. Despite the fact that eye diseases are not among the 10 most common diseases in the adult population in Poland, they are the second most common group of diseases in the population of children under 15 years, affecting $5 \%$ of people in this age group. The report also indicates that in Poland one in four people have vision problems despite the use of glasses. In the age group of people aged 70 years and above, one in two people has visual impairment or does not see at all $[3,4]$.

Refractive errors, age-related macular degeneration (AMD), glaucoma, diabetic retinopathy and other eye complications of diabetes and cataracts there are the most common eye diseases in Poland.

Myopia is the most common refractive error in children and teenagers in Poland. Currently, it affects over $40 \%$ of the population aged 0-19 years in Europe [5]. Due to the observed steady increase in the percentage of people with myopia in Asian and American countries, it should be expected that also in Poland the number of people with myopia will increase.

Presbyopia affects elder people and the percentage of people with presbyopia significantly increase in the group aged $50-54$ years and reaches over $50 \%$ in group of people aged 65 years and above. The number of people with presbyopia will increase with the aging of the population.

Currently, there are about $2 \mathrm{mln}$ people suffering from AMD in Poland. There are approximately 200,000 new cases of AMD every year. Early detection of AMD is the crucial factor for vision protection. About $85 \%$ of people with wet AMD is blind or suffering from severe visual impairment if there are not treated in time. Unfortunately, according to the data, $20-30 \%$ of patients with AMD are diagnosed too late $[6,7]$. Due to the aging of Polish population, a significant increase in the number of patients with AMD should be expected in the coming decades. According to the calculations of the Institute of Innovative Economy, the number of people suffering from AMD in Poland will increase from $2.7 \mathrm{mln}$ in year 2017 to $3.5 \mathrm{mln}$ in year 2030 [8].

Glaucoma occurs in about 2-3\% of the population aged 40 years and above. There are about 800,000 people with glaucoma in Poland, but it seems that this is just about 50\% of all people with glaucoma, because rest of $50 \%$ still remain undiagnosed. About $60 \%$ of glaucoma cases are detected accidentally during the standard eye examinations. Unfor- tunately, $70 \%$ of all glaucoma cases are detected too late. It is predicted that by year 2050 the number of glaucoma cases in Poland will increase by $120 \%$ [9].

Diabetic retinopathy is one form of the eye complications of diabetes. About $10 \%$ of the population, or about $3.5 \mathrm{mln}$ people in Poland, suffer from diabetes, but only about $2.5 \mathrm{mln}$ are diagnosed. Diabetic retinopathy occurs in about $75 \%$ of people with diabetes after 20 years of disease. It is expected that by year 2030 that the number of people suffering from diabetes will increase to over $3.0 \mathrm{mln}$ diagnosed people [10]. This will be accompanied by an increase in the number of people with diabetic retinopathy.

There are also around $1.0 \mathrm{mln}$ people with cataracts in Poland. It is estimated that the number of cataracts will increase due to the aging of the population and will reach about $1.3 \mathrm{mln}$ people in 2030 .

According to the global trends in the incidence of eye diseases and based on local forecasts, it is expected that in the next 10 years the number of people suffering from chronic eye diseases in Poland will increase by about $30 \%$. It means that about $8.2 \mathrm{mln}$, mainly people aged 50 years and above (fig. 3). The increase in the incidence of refractive errors and the incidence of chronic eye diseases will soon become a challenge for the existing ophthalmic care system in Poland.

\section{REDUCTION IN THE AVAILABILITY OF OPHTHALMIC CARE}

According to the year 2019 Barometr Watch Health Care report, the average waiting time for guaranteed health services in the field of ophthalmology in Poland was 3.8 months and this time slightly increased by 0.4 months compared to year 2018. However, this time is twice as long compared to the data from year 2012 [11, 12]. It should be emphasized that the waiting time for guaranteed health services in the field of ophthalmology has been extended, despite the introduction of a regulation at the beginning of year $2015 \mathrm{im}$ posing the obligation to have a referral to an ophthalmologist, issued by a family doctor for new ophthalmic patients. Due to the significant limitations in access to ophthalmologists during the COVID-19 epidemic, a further, significant extension of the waiting time for an ophthalmologist appointment should be expected. In addition, some people do not visit an ophthalmologist, but directly visiting hospital emergency departments.

\section{SHORTAGE OF OPHTHALMOLOGISTS AND SUPPORT OPHTHALMIC STAFF}

According to the data of the General Medical Chamber, there were 4,719 ophthalmologists practicing their profession out of 5,169 of all registered ophthalmologists at the beginning of year 2020 in Poland [13]. 


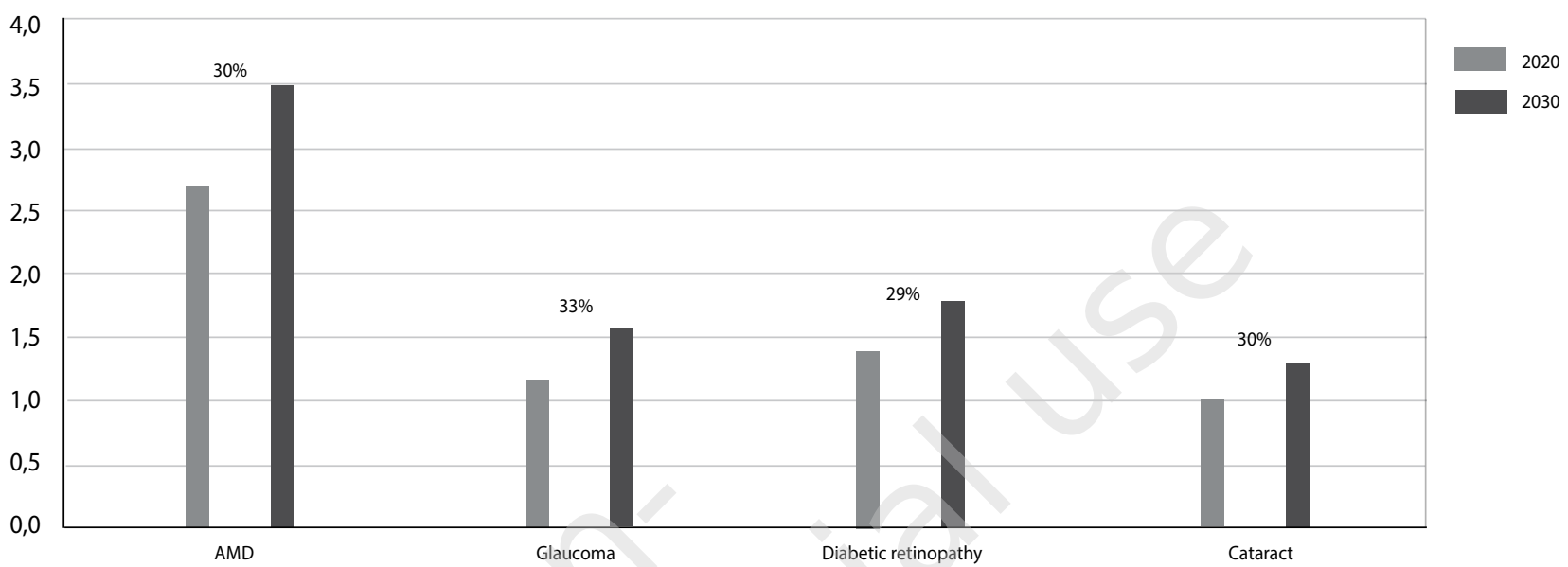

Ophthalmologists are mainly in age over 50 years $(69.7 \%$ of all ophthalmologists in Poland). Among ophthalmologists there are no people in age under 30 years (which is understandable due to the long duration of the specialization), and in the age groups 31-40 years and 41-50 years there are 602 and 1,061 of them, respectively (tab. 1) [14]. This data indicate there will be a decrease in the number of ophthalmologists in the age groups with the highest skills and possibilities to perform intensive professional work (age group 30-60 years) in the next 10 years. According to the data of the Postgraduate Medical Education Center, the number of doctors who specialize in ophthalmology has increased by over $50 \%$ during last 10 years, but so far this is not reflecting on the number of ophthalmologists in Poland.

\section{TABLE ( 1}

\section{Number of ophthalmologists in different age groups} in Poland in year 2017 [14].

\begin{tabular}{c|c} 
Age group & Number of ophthalmologists \\
\hline under 30 & 0 \\
\hline $31-40$ & 602 \\
\hline $41-50$ & 1,061 \\
\hline $51-60$ & 1,470 \\
\hline $61-70$ & 749 \\
\hline above 70 & 616 \\
\hline TOTAL & $\mathbf{4 , 4 9 8}$
\end{tabular}

There is 1.23 of ophthalmologists per 10,000 inhabitants in Poland. This indicator is comparable to the indicator presented in the Blue Book published in 2017, which presents data on the number of ophthalmologists, optometrists and opticians in European countries. According to the Blue Book, the number of ophthalmologists per 10,000 inhabitants in Poland is 1.09 , which is comparable to the average value for all reporting countries, which is 1.03 ophthalmologists per 10,000 inhabitants. According to the report, there is a significant shortage of optometrists and opticians in Poland. In the case of optometrists their average number is 0.44 per 10,000 inhabitants, and for all countries covered by the report 1.20 . In the case of opticians, their average number per 10,000 inhabitants of Poland is 1.29 , and the average for all countries is 1.63 (fig. 4) [15]. Poland is the only country in the report where the profession of optometrist is not legally defined. From a legal point of view, the profession of optometrist belongs to unregulated medical professions, in accordance with point 229 of the annex to the Regulation of the Minister of Labor and Social Policy of August $7^{\text {th }}, 2014$. This means that in the absence of top-down regulations granting appropriate powers to a given medical profession, the qualification of a given profession is determined by the scope of its activity and the fact of acquiring professional qualifications, which, however, are not specified. In addition to optometrists, nurses also play an important role in the functioning of ophthalmic care system. Despite the increase in the number of nurses in Poland and the continuous increase in the share of people with higher education in this professional group, $81 \%$ of all nurses in Poland are aged $41-70$ years. This means, similarly to ophthalmologists, that in the next 10 years there will be a significant shift in the average age in this age group and a shortage of nurses, also in the ophthalmic care system [16]. According to the data of the General Chamber of Nurses and Midwifes, by December 2020, 130 nurses completed a specialist course in Nursing in eye diseases, and 31 nurses completed a specialist course in Comprehensive nursing care in eye diseases for nurses. 

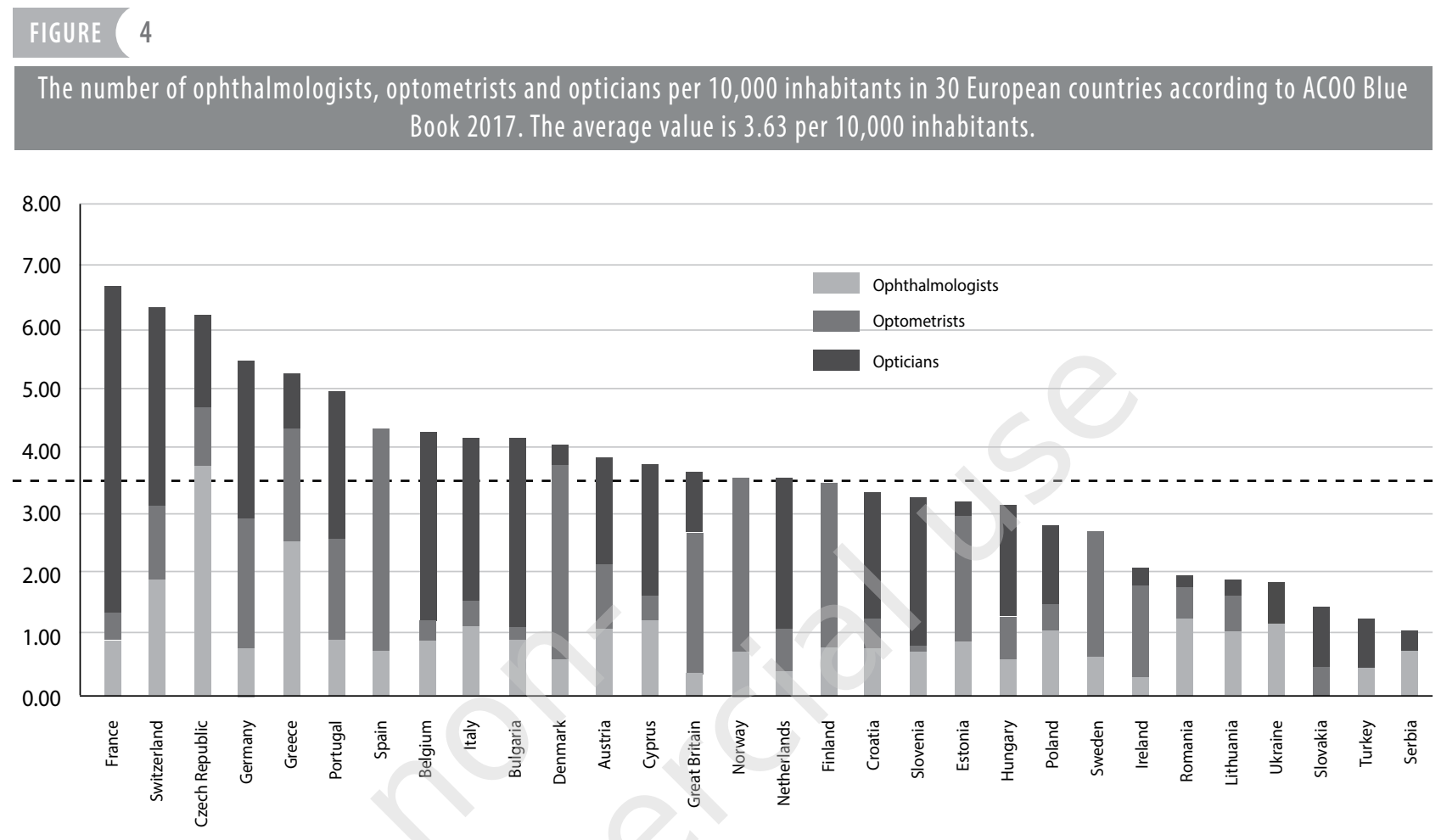

\section{LOW SOCIAL AWARENESS OF EYE DISEASES}

Prevention of chronic eye diseases according to WHO guidelines should include educational and promotional activities, limiting the impact of risk factors and detecting diseases at their early stage. Proper prophylaxis becomes particularly important in connection with the expected significant increase in the number of people with refractive errors and patients with chronic eye diseases. For many years, educational activities have been carried out to increase public awareness of chronic eye diseases. Educational activities are carried out by various organizations, such as the AMD Association, the Retina AMD Association, the Polish Ophthalmological Society, ophthalmologists and pharmaceutical companies. Every year, the Days of Sight, Glaucoma and Diabetes are celebrated. Despite so many activities, public awareness of chronic eye diseases seems to be still low. In the results of a study published in year 2017, which was carried out among the residents of Lublin, it was found that $61.4 \%$ of respondents contact an ophthalmologist only in the event of eye problems, and only $9.1 \%$ of respondents have regular ophthalmological examination. The percentage of people who do not perform systematic eye examinations is the highest among young people (18-30 years old; $91.3 \%$ ) and decreases with age. However, in people above 50, this percentage is still high and amounts to $29.5 \%$ [17].

\section{CONCLUSION}

The aging of the society and the related increase in the incidence of refractive errors and chronic eye diseases such as: presbyopia, AMD, diabetic retinopathy, glaucoma and cataracts, increased myopia, reduced availability of ophthalmic care, shortage of ophthalmologists and supporting staff, and low social awareness of diseases eyes are just selected problems of the ophthalmic care system in Poland. In order to improve the functioning of the ophthalmic care system, systemic measures should be taken as soon as possible, which will contribute to increasing the availability of ophthalmic care, early detection and systematic monitoring of the course of chronic eye diseases, and improvement of social awareness of ophthalmic diseases [18].

\section{CORRESPONDENCE}

Maciej Osęka, MD, PhD

Foundation of the Prevention of Eye Diseases

phone: +48605474781

e-mail:moseka@fpcnw.pl
ORCID

Maciej Osęka - ID - http://orcid.org/0000-0002-8017-3432

Agnieszka Jamrozy-Witkowska - ID - http://orcid.org/0000-0002-3808-8429 Małgorzata Mulak - ID - http://orcid.org/0000-0003-3598-6693 


\section{References}

1. Notatka GUS na posiedzenie Sejmowej Komisji Polityki Senioralnej dotyczące „Informacji Ministra Zdrowia na temat wpływu zmian demograficznych i starzenia się społeczeństwa na organizację systemu ochrony zdrowia i Narodowy Program Zdrowia" (19.02.2016 r.).

2. Rocznik Demograficzny - Główny Urząd Statystyczny 2018.

3. Stan zdrowia ludności Polski w 2014 roku - Główny Urząd Statystyczny 2014.

4. Partyka O, Wysocki MJ. Epidemiologia chorób narządu wzroku oraz infrastruktura okulistyki w Polsce. Przegl Epidemiol. 2015;69: 905-8.

5. Grzybowski A, Kanclerz P, Tsubota $\mathrm{K}$ et al. A review on the epidemiology of myopia in school children worldwide. BMC Ophthalmol. 2020; 20: 1-11.

6. Stankiewicz A (ed). Zatrzymać epidemię ślepoty. Medyczny, społeczny i ekonomiczny obraz schorzeń siatkówki oka. Stowarzyszenie AMD, PZN, Retina AMD, Warszawa 2012.

7. Figurska M, Matysik-Woźniak A, Adamiec-Mroczek J et al. One-year outcomes of the Polish treatment program for the wet form of age-related macular degeneration using intravitreal therapy. Eur J Ophthalmol. 2020; 30: 586-94.

8. Nojszewska $\mathrm{E}$ (ed). Ocena ekonomicznych kosztów obciążenia społecznego zaburzeń siatkówki ze szczególnym uwzględnieniem DME i AMD. Raport Instytut Innowacyjna Gospodarka, Warszawa 2018.

9. Jaskra - podstawowe informacje. Polskie Towarzystwo Okulistyczne, Medycyna Praktyczna 2015.

10. Cukrzyca 2025. Strategia prewencji i leczenia cukrzycy w Polsce 2015-2025. Instytut Praw Pacjenta i Edukacji Zdrowotnej, Koalicja na Rzecz Walki z Cukrzycą.

11. Barometr Fundacji Watch Health Care nr 19/15/02/2019. www.korektorzdrowia.pl.

12. Dostęp do opieki okulistycznej w Polsce. Podejście systemowe. Watch Health Care 2012.

13. Zestawienie liczbowe lekarzy i lekarzy dentystów wg dziedziny i stopnia specjalizacji. Naczelna Izba Lekarska 2020.

14. Muc R, Pinkas J, Kołodziejski Ł et al. Finansowanie świadczeń okulistycznych w Polsce. Post N Med. 2017; 3: 117-23.

15. ECOO Blue Book. Data on optometry and optics in Europe. The European Council of Optometry and Optics. Belgium 2017.

16. Opracowano na podstawie danych dostępnych na stronie Naczelnej Izby Pielęgniarek i Położnych. www.nipip.pl.

17. Kozłowski P, Kozłowska M, Kozłowska K. Prevention of eye diseases among the residents of Lublin, Poland. J Educ Health Sport. 2017; 7: 177-82.

18. Osęka M, Jamrozy-Witkowska A, Mulak M. System wczesnego wykrywania wad refrakcji i przewlekłych chorób oczu w Polsce. Stan obecny oraz propozycje rozwiązań na lata 2020-2030. Fundacja Profilaktyki Chorób Narządu Wzroku, Warszawa 2020. 


\section{Authors' contributions:}

Maciej Osęka: concept of the publication, data search and collecting, writing;

Agnieszka Jamrozy-Witkowska: data analysis, literature search;

Małgorzata Mulak: professional consultancy, internal reviewing.

\section{Conflict of interest:}

None.

Financial support:

None.

\section{Ethics:}

The content presented in the article complies with the principles of the Helsinki Declaration, EU directives and harmonized requirements for biomedical journals. 